\title{
ОСОБЛИВОСТІ ФОРМУВАННЯ ПРОФЕСІЙНО ВАЖЛИВИХ ЯКОСТЕЙ ПІД ЧАС ПРОФЕСІЙНОГО СТАНОВЛЕННЯ МАЙБУТНІХ ПСИХОЛОГІВ
}

\author{
Бацилєва О. В., Пузь I. B.
}

\section{ВСТУП}

Сучасний стан розвитку професійної психологічної освіти характеризується виникненням суперечливої ситуації, яка пов'язана насамперед із тим, що популярність психологічних знань серед населення призвела до стійкого високого попиту на отримання психологічної освіти, як базової, так і додаткової. При цьому досить поширеними є випадки, особливо серед молоді, коли професійний вибір відбувається без чіткого уявлення про те, в чому полягає специфіка вибраної ними професії, а більшою мірою під впливом існуючих у суспільстві міфів про психологію та психологів ${ }^{1}$.

Аналізуючи ситуацію, яка склалася сьогодні на ринку праці та освітніх послуг, не можна не відмітити той факт, що все частіше можна спостерігати виникнення невідповідності між особливостями організації навчально-виховного процесу та врахуванням індивідуально-психологічних особливостей студента, між психофізіологічними та психологічними можливостями особистості молодого фахівця і вимогами вибраної професії. На жаль, наявність такої тенденції призводить до збільшення дипломованих психологів, які виявляються цілком не готовими до виконання професійної діяльності, що знаходить своє відображення у зниженні їхньої психічної стійкості, створює загрозу професійній безпеці та заважає подальшому особистісному та професійному розвитку. 3 огляду на це стає зрозумілим, що одним із пріоритетних завдань сучасної вищої психологічної освіти має стати вирішення проблеми поєднання

1 Бацилєва О. Пузь І. В. Проблема формування готовності до професійної діяльності у майбутніх психологів. Психологічна освіта в Україні: традиції, сучасність та перспективи, 21-22 квітня 2017 року. Матеріали Всеукраїнської науково-практичної конференції з нагоди святкування 50-річчя від початку фахової підготовки психологів у КНУ імені Тараса Шевченка та Дня психолога. 2017. C. 21-23.

${ }^{2}$ Антонова Н. О. Кризові явища у професійному становленні студентів-психологів та психологів- практиків. Актуальні проблеми психологї̈. T. V: Психофізіологія. Психологія праці. Експериментальна психологія. 2007. Вип. 4. С. 3-9. 
науково-теоретичної та практичної підготовки, результатом чого має стати формування у молодих фахівців особистісної і професійної готовності до діяльності в певних умовах.

Специфіка професійної діяльності психолога, різноманітність методів, які він активно застосовує в процесі вирішення цілої низки професійних завдань, висуває до фахівця цієї галузі певні вимоги щодо його особистісного та професійного розвитку. Успішне професійне становлення психолога має супроводжуватися його особистісним i духовним зростанням. Не аби яке значення в цьому процесі набуває сформована система професійно-важливих якостей, завдяки яким стає можливим не тільки швидко адаптуватися до мінливих умов дійсності та практичних завдань, але й розвивати мотивацію до виконання діяльності на високому професійному рівні, що, безумовно, сприяє конкурентоспроможності фахівця на ринку праці. Отже, з огляду на це стає зрозумілим, що сьогодні особливої актуальності набувають питання, пов'язані з дослідженням проблеми формування професійноважливих якостей у майбутніх психологів, оскільки саме це утворення виступає головною передумовою ефективного професійного становлення студентів, формування їхньої професійної компетентності та успішної подальшої реалізації професійної діяльності.

Метою нашої роботи став теоретичний аналіз проблеми формування професійно-важливих якостей майбутніх психологів під час професійного становлення.

\section{1. Особливості професійного становлення майбутніх психологів}

Загальновідомим $є$ той факт, що професійна діяльність займає значну частину життя людини. Життєва практика свідчить, що самопочуття людини, іiі задоволеність власним життям, особливості іiі фізичного та психічного здоров'я багато в чому визначаються задоволеністю змістом професійної діяльності, ставленням до неї. Виходячи 3 цього, стає зрозумілим, що сьогодні особливої актуальності набувають питання, пов'язані з дослідженням проблеми професійного становлення особистості, тому що саме розуміння особливостей цього процесу сприяє не тільки якісній підготовці кадрового потенціалу на досить високому професійному рівні, але й сприяє подальшому ефективному особистісному становленню фахівця.

Досліджуючи проблему професійного становлення майбутніх психологів, необхідним є загальне розуміння поняття «професійного становлення фахівця» у психологічній науці. Так, під професійним становленням фахівця розуміють процес прогресивної зміни його особистості внаслідок соціальних впливів, професійної діяльності та власної активності, спрямованої на самовдосконалення i 
самоздійснення. При цьому професійне становлення обов'язково передбачає потребу в розвитку і саморозвитку, можливість і реальність iii задоволення, а також потребу в професійному самозбереженні ${ }^{3}$.

Професійне становлення можна розглядати як формування професійної спрямованості, компетентності, соціально значущих та професійно важливих якостей і їх інтеграції, готовність до постійного професійного зростання, пошук оптимальних прийомів якісного виконання діяльності у відповідності до індивідуально-психологічних особливостей людини.

Різні аспекти професійного становлення досить широко висвітлені в теоретичних та прикладних дослідженнях, як зарубіжних, так i вітчизняних учених (О. Асмолов, Г. Балл, І. Бех, О. Бодальов, Б. Боришевський, Л. Виготський, В. Дружинін, Д. Ельконін, Е. Еріксон, Д. Зіглер, О. Леонтьєв, Б. Ломов, С. Максименко, В. М'ясищев, Г. Олпорт, К. Роджерс, Л. Хьєл, К. Юнг та інші). Слід зазначити, що професійне становлення розглядається у психології в контексті загальної проблеми життєвого становлення особистості.

У сучасній психологічній науці можна відмітити неоднозначність у розумінні поняття «професійне становлення» в межах різних наукових підходів. Так, 3 позиції діяльнісного підходу (Г. Балл, Є. Зеєр, Є. Клімов та ін.) професійне становлення розглядається як процес входження людиною в професію, проходження нею певних етапів професійного розвитку. Основними показниками ефективності цього процесу $є$ формування професійного досвіду та професійно важливих якостей, ${ }^{4,}$. Відповідно до положень системно-структурного підходу професійне становлення особистості розглядається через взаємозв'язок і цілісність професійних здібностей та професійно важливих якостей, що зумовлюють успішність діяльності. У межах ціннісномотиваційного підходу (О. Борисова, І. Сапогова, В. Шадріков та інші) головним аспектом професійного становлення виступає розвиток професійної мотивації на основі формування ціннісних орієнтацій 6 .

У дослідженнях В. Бодрова, А. Маркової, Т. Кудрявцева професійне становлення ототожнюється 3 процесом професіоналізації особистості, результатом якого $\epsilon$ набуття соціальної зрілості, розвиток нових професійно важливих якостей особистості, перехід на наступний рівень

3 Кокун О.М. Психологія професійного становлення сучасного фахівця : монографія. Київ, 2012. 200 с.

${ }^{4}$ Климов Е.А. Психология профессионала. Москва, Воронеж, 1996. С. 400.

5 Зеер Э.Ф. Психология профессионального развития: учеб. пособие. Москва, 2007. $240 \mathrm{c}$.

6 Кокун О.М. Психологія професійного становлення сучасного фахівця : монографія. Київ, 2012. 200 с. 
професіоналізму. Згідно з такою позицією ефективність професійного становлення визначається об'єктивними показниками, які дозволяють оцінити міру відповідності особистості вимогам професії, та суб'єктивними, що виявляють ступінь відповідності професійної діяльності вимогам особистості .

Професійне становлення людини охоплює тривалий період іiі життя, під час якого відбувається трансформація життєвих та професійних планів, зміна соціальної ситуації, провідної діяльності, що, безумовно, відображається на функціонуванні особистості. Враховуючи динамічний характер професійного становлення фахівця, дослідниками прийнято в цьому процесі виокремлювати певні періоди чи стадії, основними критеріями для визначення яких можуть бути: ставлення особистості до професії та рівень виконання нею професійної діяльності (Т. Кудрявцев); рівень професіоналізму особистості (К. Маркова); ступінь професійної зрілості (Дж. Сьюпер); соціальна ситуація розвитку та характер провідної діяльності (Е. Зеєр).

За Е.О. Климовим, основними стадіями розвитку людини як суб'єкта праці, починаючи із самого початку опанування професії, $є$ такі: оптант, адепт, адаптант, інтернал, майстер, авторитет, наставник. Пропонуємо коротко розглянути зміст представлених стадій. Так, стадія «оптант» - це стадія підготовки до життя, до праці, свідомого і відповідального планування і вибору професійного шляху. На цій стадії людина знаходиться в ситуації професійного самовизначення. Тому в ситуації «оптанта» може бути не тільки молода людина, але й доросла, яка не має фаху або роботи. Стадія «адепт» - це стадія професійної підготовки, яку проходить більшість випускників. Стадія «адаптант» це стадія входження у професію після завершення професійного навчання. Ця стадія може тривати від декількох місяців до 2-3 років. Стадія «інтернал» - стадія входження в професію як повноцінного колеги, здатного стабільно працювати на нормальному рівні. Стадія «майстер» - коли працівник помітно виділяється серед колег, про нього можна сказати, що він $є$ кращим серед гарних. Стадія «авторитет»- це стадія, коли про фахівця можна сказати, що він став «кращим серед майстрів». Стадія «наставник» - це стадія, яка характеризує вищий рівень роботи будь-якого фахівця; працівник не тільки компетентний фахівець у своїй галузі, але й Учитель, який здатний передати кращій свій досвід учням ${ }^{8}$.

7 Яремчук В.О. Психологічні особливості становлення майбутніх фахівців соціономічних професій. URL: http://ukrlogos.in.ua/documents/ 01_12_2017_18.pdf

${ }^{8}$ Климов Е. А. Психология профессионала. Москва, Воронеж, 1996. С. 400. 
Досліджуючи проблему професійного становлення, Ю. П. Поваренков у цьому процесі виокремлює п'ять основних стадій: 1) стадія допрофесійного розвитку; 2) стадія пошуку і вибору професії (оптація); 3) стадія професійного навчання; 4) стадія самостійної професійної діяльності; 5) стадія післяпрофесійного розвитку'

На думку В. А. Гупаловської, професійна самореалізація особистості має поетапну структуру. Так, на першому етапі відбувається професійне самовизначення особистості, що передбачає вибір професії та отримання професійної освіти. На другому етапі професійний розвиток особистості має бути спрямований на професійну адаптацію; апробацію теоретичних знань у практичній діяльності; професійне самовдосконалення, підвищення кваліфікації. Третій етап професійного становлення особистості має бути присвячений підвищенню рівня професіоналізму, набуттю професійного авторитету, прояву активності, самостійності, творчого підходу в професійній діяльності.

Основними особистісними складниками, які визначають зміст професійного становлення фахівця, на думку Е. Зеєра, виступають: спрямованість особистості, професійна компетентність, професійно важливі якості, професійно значимі психофізіологічні властивості ${ }^{10}$. Пропонуємо коротко розглянути зміст вищезазначених компонентів. Так, спрямованість особистості характеризується системою домінуючих потреб, мотивів, відносин, ціннісних орієнтацій та установок. Професійна компетентність - це сукупність професійних знань, умінь, а також способів виконання професійної діяльності. Професійно важливі якості (ПВЯ) - це психологічні якості особистості, що визначають продуктивність професійної діяльності. Слід зазначити, що ПВЯ є багатофункціональними, проте кожна професія має свій набір таких якостей. Професійно значимі психофізіологічні властивості - це такі властивості людини, як зороворухова координація, нейротизм, екстраверсія, реактивність, енергетизм тощо. Розвиток цих властивостей відбувається вже в ході освоєння професії. При цьому в процесі професіоналізації одні психофізіологічні властивості визначають розвиток професійно важливих якостей, інші здобувають самостійне значення.

Важливими психологічними передумовами успішного та ефективного професійного становлення виступають сформований

9 Поваренков Ю. П. Системогенетическая концепция профессионального становления человека. Идея системности в современной психологии. Москва. 2005. C. $380-384$. $240 \mathrm{c}$.

${ }^{10}$ Зеер Э. Ф. Психология профессионального развития: Учеб. Пособие. М., 2007. 
інтелектуальний потенціал, адекватна самооцінка, емоційна зрілість особистості, її здатність до саморегуляції ${ }^{11}$. У дослідженнях А. Деркача та В. Зазикіна наголошується про те, що в процесі професійного становлення відбуваються певні трансформації в структурі особистості, насамперед у зміні характеру особистісної спрямованості, накопиченні досвіду та підвищенні кваліфікації, розвитку складних особистісних здібностей, формуванні професійно важливих якостей, які мають визначатися безпосередньо специфікою діяльності, підвищенні психологічної готовності до діяльності в різноманітних умовах ${ }^{12}$.

Таким чином, узагальнюючи вищевикладене, ми дійшли висновку, що професійне становлення визначається як продуктивний розвиток особистості у процесі засвоєння тієї чи іншої професійної діяльності. У цьому процесі можна виокремити певні стадії, послідовність проходження яких забезпечує набуття фахівцем відповідного рівня професіоналізму. На нашу думку, особливе значення в процесі професійного становлення майбутнього фахівця має етап навчання в закладі вищої освіти, оскільки саме цей період життєвого шляху людини $\epsilon$ найбільш сензитивним не тільки в процесі формування адекватного ставлення до майбутньої професії, але й розвитку професійно важливих якостей, особливості яких визначають успішність та ефективність виконання професійних завдань та обов'язків фахівців будь-якої галузі.

Проблема професійного становлення майбутнього психолога широко висвітлюється в роботах таких вітчизняних вчених, як О. Бондаренко, С. Васьківська, Ж. Вірна, О. Іванова, О. Кокун, С. Максименко, В. Панок, Н. Пов’якель, Л. Терлецька, Л. Уманець, Н. Шевченко, Н. Чепелева, Т. Яценко та ін ${ }^{13}$. Увагу науковців привертають питання, які пов'язані 3 дослідженням розвитку професійного мислення, комунікативної сфери, ціннісно-смислового ставлення до майбутньої професії.

Варто відмітити, що, незважаючи на досить широке коло як теоретичних, так і прикладних досліджень, присвячених проблемі професійного становлення майбутніх психологів, натепер окреслена проблема продовжує бути однією з актуальних у психологічній науці.

11 Пузь І.В. Особливості професійного становлення особистості в сучасних умовах. Досягнення сучасної психологічної науки та практики. Матеріали II Всеукраїнської науково-практичної конферениії студентів, аспірантів і молодих вчених (м. Вінниия, 26 березня 2020 р.): тези доповідей / за заг. ред. проф. О.В. Бацилєвої. Вінниця, 2020. С.85-89.

i2 Кокун О.М. Психологія професійного становлення сучасного фахівця : монографія. Київ, 2012. 200 с.

${ }^{13}$ Основи практичної психології. За ред. В. Г. Панка. Київ, 2006. 536 с. 
Інтерес фахівців зумовлений не тільки суперечливістю окремих положень в існуючих наукових підходах до дослідження проблеми професійного становлення, але й тим, що й досі не має усталеної системи поглядів на розуміння закономірностей становлення особистості професіонала. Важливими продовжують залишатися питання динаміки формування особистісних підструктур на різних етапах професійного шляху та розвитку професійно важливих якостей майбутніх психологів ${ }^{14}$.

На думку таких дослідників, як О. А. Білобрикіна, О. Ф. Бондаренко, С. Л. Братченко, В. Г. Панок, Н. І. Пов'якель, професійне становлення майбутнього психолога на етапі навчання в навчальних закладах має відбуватися за кількома напрямами, зокрема: поглиблення професійної спрямованості, розвиток необхідних здібностей; удосконалення, «професіоналізація» психічних процесів, станів, досвіду; розвиток почуття обов'язку, відповідальності за успіх професійної діяльності; зростання рівня домагань особистості студента в галузі майбутньої професії; зростання загальної зрілості та стійкості на основі інтенсивної передачі соціального та професійного досвіду i формування необхідних якостей; підвищення рівня самовиховання студента в процесі формування якостей, досвіду, необхідних йому як майбутньому психологу; розвиток професійної самостійності i готовності до майбутньої професійної діяльності ${ }^{15}$.

Навчально-виховний процес насамперед повинен забезпечувати умови для формування у студентів-психологів таких груп інтересів, потреб, переконань, які би спрямували їх на особистісну та професійну самореалізацію і самовдосконалення ${ }^{16}$.

Професійне становлення студента-психолога у процесі підготовки вимагає від студента складної напруженої творчої роботи над розвитком власної особистості, вибору одних можливостей і відмови від інших. Важливим для майбутнього психолога $\epsilon$ досягнення найвищого рівня розвитку мистецтва жити, що відображається передусім в інтегративному вмінні й високій майстерності у творчій побудові свого життя, розвиненій самосвідомості й оволодінні

14 Крикля К.П. Психологічні особливості професійного становлення майбутнього психолога в умовах сучасного суспільства. Науковий вісник Львівського державного університету внутрішніх справ (Серія психологічна). 2012. № 2(1). C. 409-417.

15 Адамська 3. Суб' єктність у системі професійно значущих якостей особистості майбутнього психолога. Психологія особистості. 2011. № 1(2). С. 51-58.

16 Барчій М. С. До проблеми професійного становлення майбутніх психологів. Вісник Національного університету оборони України. 2015. № 3(46). С. 14-19. 
системою засобів, методів, технологій програмування, конструювання індивідуального життя ${ }^{17}$.

Основними результативними аспектами професійного становлення майбутніх психологів на етапі професійного навчання $є$ професійна спрямованість, професійна компетентність, професійно важливі якості, готовність до професійного зростання. Пропонуємо коротко розглянути зміст цих утворень. Так, професійна спрямованість студентівпсихологів проявляється в їхньому прагненні до успішного оволодіння навчальною програмою, сталою спрямованістю до ефективного використання отриманих знань, умінь та навичок під час професійно орієнтованої практики, а також у прагненні розвивати ті здібності, які дозволяють не тільки успішно оволодіти професією психолога, а й у майбутньому вдосконалюватися в обраній професійній сфері.

На думку Н. Ф. Шевченко, психологічним механізмом професійної спрямованості майбутніх психологів виступає єдність особистісних якостей та властивостей, яка включає складну багаторівневу структуру мотивів, цінностей, особистісних смислів і здібностей, що визначають професійно важливі якості, особливе місце серед яких займає психологічна грамотність, яку прийнято розглядати як оволодіння психологічними знаннями, вміннями, символами, правилами i нормативами у сфері спілкування, поведінки, психічної діяльності ${ }^{18}$.

Під час отримання професійної освіти у майбутніх психологів, як і у фахівців будь якої іншої галузі, відбувається формування професійної компетентності, яку прийнято розглядати як інтегральну характеристику, що визначає здатність вирішувати професійні проблеми i типові професійні задачі, що виникають у реальних ситуаціях професійної діяльності, з використанням знань, професійного та життєвого досвіду, цінностей та здібностей. Будучи головним компонентом підсистеми професіоналізму особистості, професійна компетентність - це сфера професійних знань, коло питань, що вирішуються, система знань, що постійно розширюються і дозволяють виконувати професійну діяльність із високою ефективністю ${ }^{19}$.

17 Прудка Л. Професійна підготовка майбутніх практичних психологів в організації навчально-виховного процесу. Вісник національного авіаційного університету. Серія Педагогіка, Психологія. 2013. № 4. URL: http://jrnl.nau.edu.ua/ index.php/VisnikPP/article/view/10144

${ }_{18}$ Шевченко Н. Ф. Підготовка практичних психологів, особистісні та професійні якості фахівців. Психологія: зб. наук. пращь КНПУ ім. Драгоманова. 2002. № 7. С. 34-38.

19 Бацилєва О. Пузь І. В. Проблема формування готовності до професійної діяльності у майбутніх психологів. Психологічна освіта в Україні: традиції, сучасність та перспективи, 21-22 квітня 2017 року. Матеріали Всеукраїнської науково-практичної конференції з нагоди святкування 50-річчя від початку фахової підготовки психологів у КНУ імені Тараса Шевченка та Дня психолога. 2017. C. 21-23. 
Необхідними умовами формування у студентів-психологів готовності до професійної діяльності, що, власне, виступає одним із головних аспектів їхнього професійного становлення, виступає успішне проходження низки стадій під час професійного навчання, а саме: адаптації, інтенсифікації, ідентифікації. Так, на стадії адаптації, яка охоплює першій рік навчання, відбувається активне пристосування студентів до умов i змісту навчально-професійного процесу, відбувається засвоєння ними нової соціальної ролі, налагодження відносин один з одним. Важливе значення на цій стадії мають як суб'єктивні (мотиви вибору професії психолога, установки на навчання, індивідуально-психологічні особливості особистості та ін.), так і об'єктивні чинники (форми та методи навчання, спрямованість академічної групи та ін.). Психологічним критерієм успішного проходження цієї стадії $\epsilon$ адаптованість до вимог навчального середовища, емоційна стабільність, особистісне самовизначення та вироблення нового стилю життєдіяльності, що сприяє самоосвіті, самоорганізації, мотивації до навчання, готовності до опанування нових знань. На другій стадії професійної підготовки - стадії інтенсифікації, яка триває протягом другого-третього курсів навчання, відбувається розвиток загальних і спеціальних здібностей студентів, інтелекту, емоційно-вольової регуляції, відповідальності за своє професійне та особистісне становлення. Провідною діяльністю на цій стадії виступає науково-пізнавальна. Конструктивне проходження цієї стадії визначається за такими показниками, як особистісний та інтелектуальний розвиток студентів, критичність та гнучкість мислення, адекватний рівень самоповаги, позитивна внутрішня мотивація до навчально-професійної діяльності. На завершальній стадії - стадії ідентифікації - передбачається формування у студентів професійної ідентичності, готовності до майбутньої професійної діяльності психолога, головними показниками якої $є$ ототожнення студентів з вибраною професією, їхнє професійне самовизначення, наявність у них адекватної самооцінки власного Я, незалежність їхніх суджень. Про неготовність випускників-психологів до виконання професійної діяльності свідчить насамперед неузгодженість структурних компонентів «Я-концепції» (Я-реального та Я-ідеального), суперечливе ставлення до себе, як до особистості та фахівця, розвиток низки особистісних деструкцій ${ }^{20}$.

${ }^{20}$ Корень Т.О. Модель професійного розвитку майбутнього психолога у вищому навчальному закладі. URL: http://virtkafedra.ucoz.ua/el_gurnal /pages/vyp4/psihologia/ koren.pdf 
Важливим під час професійного становлення особистості майбутнього психолога в ході навчання $є$ формування осмисленого ставлення до себе в контексті професійно-навчальної діяльності та до діяльності в цілісному контексті життя. Слід зазначити, що на сучасному рівні розвитку психологічної науки та практики професійне становлення студентів-психологів вимагає від них складної та напруженої творчої роботи, спрямованої на глибоке самопізнання та розвиток власної особистості. Успішність професійного становлення майбутніх психологів залежить від багатьох чинників, найбільш важливим $з$ яких виступає рівень розвитку професійної свідомості та самосвідомості, оскільки саме на підставі даних психічних утворень відбувається формування професійно важливих якостей, розвиток професійного мислення, що сприяє формуванню готовності до професійної діяльності. Розвиток професійної самосвідомості психолога є процесом і результатом усвідомлення ним самого себе в навчальний та професійній сферах, цілеспрямоване регулювання на цій основі своєї поведінки та діяльності в цілому.

\section{2. Професійно важливі якості як чинник професійного становлення майбутніх психологів}

Ефективність виконання будь-якої професійної діяльності детерміновано різного роду чинниками, серед яких особливого значення набуває сформованість відповідних професійно важливих якостей (далі -ПВЯ), які прийнято розглядати як компоненти цілісної особистості, які $є$ підгрунтям для пристосування до певної сфери професійної діяльності, формування яких відбувається на основі вроджених біопсихічних властивостей особистості.

Досліджуючи проблему формування професійно важливих якостей майбутніх психологів під час професійного становлення, необхідно більш детально розглянути особливості розуміння даного утворення в психологічній науці. Так, на думку В. Д. Шадрікова, під ПВЯ, з одного боку, можна розуміти індивідуальні якості суб'єкта діяльності, що мають безпосередній вплив не тільки на виконання діяльності, але й на успішність процесу оволодіння цією діяльністю, з іншого боку - ПВЯ можна розглядати як ті внутрішні умови, через які переломлюються зовнішні дії і вимоги до діяльності ${ }^{21}$.

У дослідженнях А. К. Маркової відмічається, що професійні якості, по-перше, виступають передумовою ефективної професійної діяльності, по-друге, вони здатні самостійно вдосконалюватися та

21 Кокун О.М. Психологія професійного становлення сучасного фахівця : монографія. Київ, 2012. 200 с. 
корегуватися. Професійні якості - це успішність в оволодінні і здійсненні фахівцем різноманітних завдань професійної діяльності. При цьому формування ПВЯ відбувається поступово, рівень їх розвитку відрізняється на різних етапах досягнення особистістю професійної майстерності. Згідно з тлумаченням Б. О. Душкова, ПВЯ розглядаються як окремі динамічні властивості особистості, iї психічні і психомоторні властивості, а також фізичні якості, які відповідають вимогам певної професії і сприяють успішному оволодінню нею 22.

У дослідженні Е. Зеєра відзначається, що розвиток професійно важливих якостей відбувається в контексті формування особистості в цілому, під час процесу її професійного становлення ${ }^{23}$.

Отже, виходячи 3 положень представлених підходів, стає зрозумілим, що професійно важливі якості - це внутрішні психологічні характеристики суб'єкта, що відображаються у професійній діяльності, сприяють ефективності розв'язання професійних завдань, особистісному професійному зростанню й самореалізації у процесі здійснення професійної діяльності.

Сучасна професійна діяльність психолога передбачає різноманітні спеціалізації, які мають свої специфічні особливості. У зв'язку з цим відповідно до різних сфер психологічної практики професійно важливими якостями виявляються різні, а іноді й протилежні здібності й особистісні властивості. Але разом із цим можна виокремити комплекс загальних професійно важливих якостей, який виступає основою ідеальної моделі висококваліфікованого фахівця, а також визначає гармонійний розвиток особистості психолога. Так, до таких професійно важливих якостей відносяться гуманізм, емоційна чутливість, соціальна зрілість, моральність, висока комунікативність, толерантність, емпатійність, здатність до рефлексії, щирість, дружелюбність, відкритість, активність, відповідальність, інтелектуальність, емоційна стійкість, витривалість, уважність, пластичність і динамічність мислення, збалансованість i гармонійність рис особистості, відсутність внутрішніх конфліктів, висока працездатність та дисциплінованість, адекватна самооцінка, здатність до самовдосконалення та самопізнання, самокритичність тощо.

Розглядаючи процес підготовки студентів-психологів до професійної діяльності, можна відмітити його деякі специфічні особливості. Так, по-перше, професійна підготовка має розглядатися як

\footnotetext{
22 Адамська 3. Суб' єктність у системі професійно значущих якостей особистості майбутнього психолога. Психологія особистості. 2011. № 1(2). С. 51-58.

23 Зеер Э. Ф. Психология профессионального развития: учеб. пособие. М., 2007. $240 \mathrm{c}$.
} 
підготовка до практичної психологічної діяльності, а не до праці загалом. По-друге, підготовка має бути спрямована на формування тих якостей особистості, що забезпечують досягнення успіху в певному напрямі діяльності психолога. По-трете, процес підготовки має охоплювати всі сторони особистості ${ }^{24}$.

Під час отримання професійної освіти майбутній психолог повинен активно формувати свою професійну майстерність та здійснювати роботу щодо самовдосконалення своєї особистості. 3 огляду на це стає зрозумілим, що професійна підготовка студентів-психологів виступатиме як свідомий вплив на особистість, результатом якого має стати його формування як активного суб'єкта діяльності, як зрілої особистості з професійно-важливими якостями.

Аналізуючи результати досліджень (О. Ф. Бондаренко, В. Г. Панок та інші), можна відмітити той факт, що становлення особистості майбутнього психолога під час отримання ним професійної освіти має відбуватися за такими напрямами, як поглиблення професійної спрямованості та розвиток необхідних здібностей; удосконалення психічних процесів, станів, досвіду; розвиток почуття обов'язку та відповідальності за успіх майбутньої професійної діяльності; зростання загальної зрілості та стійкості особистості; формування професійної самостійності й готовність до майбутньої практичної діяльності ${ }^{25}$.

На думку таких провідних українських вчених, як С. Д. Максименко, О. Ф. Бондаренко, В. В. Панок, Н. В. Чепелєва, майбутні психологи під час навчання повинні розвивати в себе професійне мислення; соціальну активність; здібності до прогнозування, імпровізації; загальну та психологічну культуру тощо.

Результати власних спостережень, які збігаються 3 результатами досліджень, присвячених виявленню особливостей формування професійно важливих якостей майбутнього психолога, показали, що цей процес залежить не лише від організації та якості навчального процесу, але й від цілої низки особистісних властивостей самого студента, серед яких особливе значення мають особливості мотивації під час навчального процесу, локус контролю, осмислене ставлення до себе та до діяльності, здібність до рефлексії, сформована комунікативна компетентність. Провідна роль вищезазначених компонентів у процесі формування професійно важливих якостей майбутнього психолога

24 Марценюк М.О. Особливості професійної та особистісної готовності психолога до професійної діяльності. Міжнародний науковий вісник: збірник наукових праць. Ужгород, 2014. Вип. 2(9). С. 366-382.

${ }_{25}$ Основи практичної психології / за ред. В.Г. Панка. Київ, 2006. 536 с. 
вимагає їх поглибленого вивчення як із практичної, так і теоретичної точки зору ${ }^{26,27}$.

Так, розглядаючи зміст навчальних мотивів, прийнято виокремлювати внутрішні й зовнішні мотиви. До внутрішніх мотивів, пов'язаних зі змістом навчально-професійної діяльності та іiі виконанням, належать власний розвиток у процесі навчання, прагнення до пізнання нового, взаємодія разом з іншими оточуючими людьми. Зовнішні мотиви навчання представлені ставленням до процесу навчання як до звичного функціонування, при цьому навчання виступає заради лідерства та престижу, прагнення опинитися в центрі уваги. Варто відзначити, що наявність таких мотивів частіш за все має негативний вплив на процес професійного становлення. Важливим критерієм розвитку майбутнього психолога $\epsilon$ відповідний рівень професійної мотивації, який визначається сукупністю навчальнопрофесійних, значущих для особистості мотивів, які грунтуються передусім на стійкому інтересі студента до майбутньої професії i визначаються спрямованістю на оволодіння професією та готовністю до іiі реалізації на високому рівні ${ }^{28}$.

Слід також зазначити, що внутрішні механізми мотивації особистості можна представити через інтернальний (внутрішній) локус контролю, який прийнято розглядати як одну 3 найважливіших інтегральних характеристик самосвідомості, що пов'язує почуття відповідальності, готовності до активності. Аналіз результатів досліджень свідчить про те, що характерним для людей 3 домінуючим інтернальним локусом контролю $є$ почуття соціальної відповідальності, вищий рівень усвідомленості життя. У таких людей відмічаються виражені риси товариськості, відвертості, самоконтролю, прийняття свого Я, емоційної стійкості та врівноваженості, тоді як людям 3 екстернальним (зовнішнім) локусом контролю, навпаки, властиві підозрілість, тривожність, конформність, авторитарність, безпринципність i агресивність. Отже, виходячи 3 цього, стає зрозумілим, що внутрішній локус контролю $є$ надзвичайно важливою передумовою для успішної професійної діяльності та вказує на

26 Пузь I.В., Шевченко О.М. Значення комунікативної компетентності у професійному становленні майбутніх психологів. Психологічний журнал. 2018. № 4(14). С. 149-164.

27 Євдокимова Н.О., Партенадзе О.В., Біда А.М. Моделювання розвитку професійно важливих якостей майбутнього психолога у сфері тренінгових технологій. Збірник наукових праць. Психологічні науки. 2014. Вип. 2.13 (109). C. $62-67$.

${ }_{28}$ Шевченко Н. Ф. Підготовка практичних психологів, особистісні та професійні якості фахівців. Психологія: зб. наук. працьь КНПУ ім. Драгоманова. 2002. № 7. C. 34-38. (74) 
впевненість особистості в собі, їі наполегливість і послідовність у досягненні мети, схильність до самоаналізу, врівноваженість, доброзичливість.

Особливого значення у процесі становлення особистості майбутнього психолога набуває осмислений характер ставлення до себе в контексті навчально-професійної діяльності та ставлення до діяльності в цілісному контексті життя. На думку О. М. Леонтьєва, специфіка періоду професійного становлення майбутнього фахівця полягає в тому, що розвиток особистості суб'єкта діяльності (студента) відбувається у формі смислової перебудови його свідомості та самосвідомості ${ }^{29}$. Під час навчання у вищому навчальному закладі у свідомості молодої людини має актуалізуватися сенс власної майбутньої професійної діяльності, що сприятиме передусім високій ефективності праці, реалізації творчого підходу до виконання своїх професійних обов'язків, орієнтації на досягнення успіху та самовдосконалення, а також позитивному ціннісно-смисловому ставленню до професії, що виявляється в переживанні професійного покликання, задоволеності професійною самореалізацією та процесом фахової підготовки, високому рівні мотиваційної готовності до майбутньої професійної діяльності ${ }^{30}$.

До числа найбільш важливих особистісних складників майбутнього психолога, безперечно, відноситься рефлективність, яка не тільки спрямовує процес мислення і прийняття рішення, але й забезпечує регулювання і саморегулювання діяльності та поведінки, збереження психофізичного й енергетичного потенціалу фахівця ${ }^{31}$.

Процес професійного становлення психолога передбачає роботу особистості над собою, яка має бути спрямована на самопізнання, саморозвиток та активізацію особистісного потенціалу. Особливе місце в системі життєвих ставлень особистості фахівця посідає безпосереднє ставлення до себе, оскільки специфіка означеної професії передбачає те, що одним із можливих інструментів його роботи, окрім спеціальних психологічних методів та методик, може виступати його власна особистість. У цьому контексті важливого значення для майбутніх психологів набуває розвиток особистісної автономії як форми

${ }^{29}$ Барчій М. С. До проблеми професійного становлення майбутніх психологів. Вісник Національного університету оборони Украӥни. 2015. № 3(46). С. 14-19. (5)

${ }^{30}$ Адамська 3. Суб'єктність у системі професійно значущих якостей особистості майбутнього психолога. Психологія особистості. 2011. № 1(2). С. 51-58.

31 Свдокимова Н.О., Партенадзе О В., Біда А.М. Моделювання розвитку професійно важливих якостей майбутнього психолога у сфері тренінгових технологій. Збірник наукових праць. Психологічні науки. 2014. Вип. 2.13 (109). С. 62-67. 
особистісного буття, інтегральна сутність якої виявляється в таких характеристиках, як самостійне цілепокладання, усвідомленість поведінки, розвинена здібність до рефлексії, гнучкість і креативність мислення й діяльності тощо. Слід зазначити, що дане поняття не варто ототожнювати ні з незалежністю, ні з емансипацією, воно виступає одним із механізмів адаптації особистості до мінливих умов дійсності, визначаючи успішність особистісного та професійного розвитку майбутнього фахівця.

Отже, узагальнюючи вищевикладене, можна відмітити той факт, що поряд із формуванням у студентів-психологів професійно-важливих якостей особливої уваги та виняткового значення набуває їхній саморозвиток, створення власного образу світу. Саме представлені особистісні властивості та якості, на нашу думку, становлять фундамент ефективної професійної діяльності психолога.

\section{ВИСНОВКИ}

Професійне становлення особистості передбачає передусім формування професійно важливих якостей та здібностей, професійних знань і вмінь. Цей процес супроводжується активним перетворенням особистістю свого внутрішнього світу, що забезпечує самореалізацію фахівця у професії.

Професійне становлення психолога на етапі професійного навчання передбачає не тільки оволодіння необхідними професійними знаннями, вміннями та навичками, але і його особистісне самовдосконалення, розвиток професійної, активізацію життєвої позиції, формування низки професійно важливих якостей, здатності до ефективної співпраці 3 іншими фахівцями. Дослідження особливостей професійного становлення майбутніх психологів дозволяє розглядати зазначений процес, 3 одного боку, як процес формування професійної спрямованості, компетентності, професійно важливих якостей, а 3 іншого боку - як процес формування готовності до постійного професійного зростання, пошуку оптимальних прийомів якісного i творчого виконання діяльності відповідно до індивідуальнопсихологічних особливостей особистості студента.

Важливим під час професійного становлення $\epsilon$ прийняття майбутніми психологами відповідальності за свій професійний розвиток. На нашу думку, саме підвищення активності студентапсихолога є одним зі значущих моментів у динаміці його професійного становлення. Лише власна активність майбутніх психологів сприяє розвитку в них нових мотивів діяльності й поведінки, закріпленню нових поглядів, переконань, нового досвіду, нових переживань, нових 
навичок, що, безумовно, є важливим у процесі їхнього професійного становлення на етапі професійного навчання.

Безперечно, формування значної кількості професійно важливих якостей майбутніх психологів можливо завдяки правильній організації процесу опанування теоретико-практичних основ психологічної науки. Проте обов'язковим $є$ усвідомлення студентом особливостей власної майбутньої професії, що буде сприяти подальшому формуванню професійної компетентності.

\section{АНОТАЦІЯ}

У роботі висвітлюється проблема формування професійно важливих якостей під час професійного становлення майбутніх психологів. Показано, що професійне становлення особистості являє собою складний процес, який зумовлений низкою факторів. Під час професійного становлення фахівця має відбуватися формування професійно важливих якостей, професійних знань i вмінь, які виступають структурними компонентами професійної компетентності фахівця.

Проаналізовано особливості професійного становлення майбутніх психологів на етапі навчання. Зазначено, що цей процес має здійснюватися в новій особистісно орієнтованій парадигмі, передбачати актуалізацію професійно важливих особистісних якостей, орієнтуватися на формування професійної компетентності, а також на створення системи професійних умінь та навичок, які сприятимуть досягненню професійного успіху, самореалізації, набуття професійної культури спілкування, професійної інтуїції, рефлексії. Формуванню професійно важливих якостей у майбутніх психологів сприяє запровадження активних методів навчання під час реалізації освітнього процесу. Встановлено, що професійно важливі якості виступають передумовою ефективного професійного становлення майбутніх психологів, формуванню їхньої професійної компетентності та успішної подальшої реалізації професійної діяльності.

\section{ЛITЕРАТУРА}

1. Адамська 3. Суб'єктність у системі професійно значущих якостей особистості майбутнього психолога. Психологія особистості. 2011. № 1 (2). С. 51-58.

2. Антонова Н.О. Кризові явища у професійному становленні студентів-психологів та психологів практиків. Актуальні проблеми психологї. 2007. Вип. 4. Т. V: Психофізіологія. Психологія праці. Експериментальна психологія. С. 3-9. 
3. Барчій М.С. До проблеми професійного становлення майбутніх психологів. Вісник Національного університету оборони Украӥни. 2015. № 3 (46). C. 14-19.

4. Бацилєва О. Пузь I.В. Проблема формування готовності до професійної діяльності у майбутніх психологів. Психологічна освіта в Україні: традииї, сучасність та перспективи, 21-22 квітня 2017 року: Матеріали Всеукраїнської науково-практичної конференції 3 нагоди святкування 50-річчя від початку фахової підготовки психологів у КНУ імені Тараса Шевченка та Дня психолога. 2017. С. 21-23.

5. Свдокимова Н.О., Партенадзе О.В., Біда А.М. Моделювання розвитку професійно важливих якостей майбутнього психолога у сфері тренінгових технологій. Збірник наукових пращь. Психологічні науки. 2014. Вип. 2.13 (109). С. 62-67.

6. Зеер Э.Ф. Психология профессионального развития : учеб. пособие. Москва, 2007. 240 с.

7. Іванова І.Ф. Вплив рівня розвитку комунікативних здібностей на формування професійної спрямованості студентів-психологів. 3б. наук. праць. Психологічні науки. 2013. Т. 2. Вип.10 (91). С. 121-125. URL: http://en.mdu.edu.ua/spaw2/uploads/files/ 26_19.pdf

8. Климов Е.А. Психология профессионала. Москва, Воронеж, 1996. C. 400 .

9. Кокун О.М. Психологія професійного становлення сучасного фахівця : монографія. Київ, 2012. 200 с.

10. Корень Т.О. Модель професійного розвитку майбутнього психолога у вищому навчальному закладі. URL: http://virtkafedra.ucoz.ua/el_gurnal/pages/vyp4/psihologia/koren.pdf

11. Крикля К.П. Психологічні особливості професійного становлення майбутнього психолога в умовах сучасного суспільства. Науковий вісних Львівського держсавного університету внутрішніх справ (Серія психологічна). 2012. № 2 (1). С. 409-417.

12. Марценюк М.О. Особливості професійної та особистісної готовності психолога до професійної діяльності. Міжнародний науковий вісник: збірник наукових пращь. Ужгород, 2014. Вип. 2 (9). C. $366-382$.

13. Основи практичної психології / за ред. В.Г. Панка. Київ, 2006. $536 \mathrm{c}$.

14. Поваренков Ю. П. Системогенетическая концепция профессионального становления человека. Идея системности в современной психологии. Москва, 2005. С. 380-384.

15. Прудка Л. Професійна підготовка майбутніх практичних психологів в організації навчально-виховного процесу. Вісник національного авіаційного університету. Серія Педагогіка, Психологія. 
2013. № 4. URL: http://jrnl.nau.edu.ua/index.php/VisnikPP/article/ view/10144

16. Пузь I.B., Шевченко О.М. Значення комунікативної компетентності у професійному становленні майбутніх психологів. Психологічний журнал. 2018. № 4 (14). С. 149-164.

17. Пузь І.В. Особливості професійного становлення особистості в сучасних умовах. Досягнення сучасної психологічної науки та практики: Матеріали II Всеукраїнської науково-практичної конференції студентів, аспірантів і молодих вчених (м. Вінниця, 26 березня 2020 р.) : тези доповідей / за заг. ред. проф. О.В. Бацилєвої. Вінниця, 2020. С. 85-189.

18. Шевченко Н.Ф. Підготовка практичних психологів, особистісні та професійні якості фахівців. Психологія: зб. наук. праць КНПУ ім. Драгоманова. 2002. № 7. С. 34-38.

19. Яремчук В.О. Психологічні особливості становлення майбутніх фахівців соціономічних професій. URL: http://ukrlogos.in.ua/documents/ 01_12_2017_18.pdf

\section{Information about the authors: Batsylyeva O. V.,} D.Sc. in Psychology, Professor, Head of the Psychology Department

Vasyl Stus National University in Donetsk 4, Academician Yangel str., Vinnytsia, 21001, Ukraine

Puz I. V., $\mathrm{PhD}$ in Psychology, Associate Professor of Department of Psychology Vasyl Stus National University in Donetsk 4, Academician Yangel str., Vinnytsia, 21001, Ukraine 